\title{
Epidermal Pigmentation, Nucleotide Excision Repair and Risk of Skin Cancer
}

\section{Perry Christian, Jillian Vanover, Timothy Scott, Greg Tullo and John A. D’Orazio*}

University of Kentucky College of Medicine, the Markey Cancer Center, the Graduate Center for Toxicology and the Departments of Pediatrics and of Molecular and Biomedical Pharmacology, Lexington, KY, 40536, USA

\begin{abstract}
As a group, malignancies of the skin are the most commonly diagnosed cancers, with over a million cases each year identified in the United States alone. While the keratinocyte malignancies - basal cell carcinoma (BCC) and squamous cell carcinoma (SCC) - represent the majority of clinical cases of skin cancer, malignant melanoma is the most deadly form of skin cancer. Each of these skin malignancies is clearly linked to UV radiation, with chronic cumulative UV exposure being most relevant for keratinocyte malignancies and intense, blistering sunburns most relevant for melanoma. In this review, we describe the epidemiology of skin cancer, the link with UV radiation, and the innate defenses used to resist UV damage with particular attention to the nucleotide excision DNA repair pathway. We also focus on the role of skin pigmentation and the molecular events that control melanization of the skin, since these signaling pathways appear to be major determinants of skin cancer risk. We are particularly interested in the melanocortin 1 receptor (MC1R) signaling pathway which influences basal skin pigmentation, the ability to tan and the efficiency by which UV-induced photolesions are repaired in melanocytes after UV exposure.
\end{abstract}

\section{Skin Cancer}

Malignancies of the skin are the most commonly diagnosed cancers in the United States, with over a million new cases diagnosed annually and more than 10,000 deaths per year. They are commonly divided into two main categories, melanoma and non-melanoma skin cancers (NMSC's). Malignant melanoma accounts for roughly $4 \%$ of skin neoplasms but is the deadliest form, accounting for $75 \%$ of skin cancer related deaths [10]. Conversely, NMSC's, derived from epidermal keratinocytes, are much more frequently diagnosed but cause fewer deaths. Basal cell carcinoma and squamous cell carcinoma together make up NMSC tumors, representing $78 \%$ and $21 \%$ of NMSC, respectively [11]. Among Caucasians, the estimated lifetime risk for basal cell carcinoma is roughly $35 \%$ for men and $25 \%$ for women. Basal cell carcinomas exhibit limited invasive and metastatic potential and are highly treatable by cryotherapy or surgical excision. Squamous cell carcinomas, on the other hand, are more aggressive and can invade deep into the skin, underlying structures, into lymph nodes and beyond, killing roughly 2,500 Americans annually. Standard treatment for localized NMSC is surgical removal, curettage and cauterization or cryosurgery, sometimes followed by radiotherapy or chemotherapy if there is clinical evidence of invasion or spread.

\section{Melanoma}

Melanoma is a neoplasm of melanocytes, the pigment producing cells of the skin. It is characterized by a tendency to metastasize early in its course, wherein it becomes highly treatment refractory. Although melanoma accounts for less than $10 \%$ of skin cancer cases in the U.S., it is responsible for $75 \%$ of all skin cancer deaths. Melanoma develops from melanocytes, neural crest-derived cells that manufacture melanin and give skin its color. Its lethality is due to its ability to invade other areas of the body early in its development, and its resistance to current forms of cancer therapy once spread beyond the primary site of disease. Malignant melanoma is diagnosed in almost 70,000 people and kills nearly 9,000 Americans each year [12]. Because of enhanced detection, an aging population and more ambient and recreational UV exposure, the incidence of melanoma incidence has increased steadily over the last several decades [13]. Whereas the disease was diagnosed only once in every 1,500 or so individuals in the 1930's, melanoma now affects roughly one in every sixty Americans. It currently ranks in the "topten" for the most commonly diagnosed malignancies for both men and women and it causes the most deaths by cancer in young adult women [14]. Melanoma incidence has more than doubled since 1973 alone, increasing at annual rate on the order of 3-7\% to become a legitimate current public health issue.

\section{Major risk factors for skin malignancies}

Although keratinocyte malignancies and melanomas display markedly different clinical characteristics, they share many common risk factors (Table 1) [15].

Skin pigmentation: Skin pigmentation is a major risk factor for developing both melanoma and non-melanomatous skin cancers, and in general, Caucasians are at much higher risk of skin malignancies than people of African, Asian or Latino descent. In the US, fair-skinned individuals are 20 times more likely to develop melanoma than their dark-skinned counterparts, with similar divergence in risk noted for BCC and SCC. Though there are many potential genetic differences between racial groups that might influence cancer risk, it is widely assumed that the major determinant of skin cancer risk is the amount

*Corresponding author: John D'Orazio, Associate Professor of Pediatrics, University of Kentucky College of Medicine, Markey Cancer Center, Combs Research Building 204, 800 Rose Street, Lexington, KY 40536-0096, USA, Tel: (859) 323-6238; Fax: (859) 257-8940; E-mail: jdorazio@uky.edu

Received November 24, 2011; Accepted December 13, 2011; Published December 17, 2011

Citation: Christian P, Vanover J, Scott T, Tullo G, D’Orazio JA (2011) Epiderma Pigmentation, Nucleotide Excision Repair and Risk of Skin Cancer. J Carcinogene Mutagene S4:001. doi:10.4172/2157-2518.S4-001

Copyright: (c) 2011 Christian P, et al. This is an open-access article distributed under the terms of the Creative Commons Attribution License, which permits unrestricted use, distribution, and reproduction in any medium, provided the original author and source are credited. 


\begin{tabular}{|c|c|}
\hline Age & - Incidences of basal cell carcinoma, squamous cell carcinoma and melanoma all increase dramatically with age. \\
\hline UV exposure & $\begin{array}{l}\text { - Skin cancer incidence is highest in areas with the most ambient sunlight exposure (equatorial, high altitude). } \\
\text { - Hccupational or recreational UV exposure. } \\
\text { - } \text { predictive of keratinocyte malignancies. } \\
\text { - Tanning bed use clearly is associated with BCC, SCC and melanoma. } \\
\text { - First exposure to indoor tanning before } 35 \text { years of age raises lifetime risk of melanoma by } 75 \%\end{array}$ \\
\hline Fair skin complexion & $\begin{array}{l}\text { - Fair skin complexion, caused by scant deposition of the highly UV-protective eumelanin pigment in the epidermis, is associated } \\
\text { with higher risk of BCC, SCC and melanoma. } \\
\text { - In fair skin, more UV penetrates into the skin and promotes mutagenesis and carcinogenesis. } \\
\text { - Albinos, who lack pigment entirely due to loss of function of melanogenic biosynthetic enzymes, are at particularly high risk for } \\
\text { skin cancer (particularly BCC and SCC). } \\
\text { - Cancer risk is also associated with an inability to tan adaptively. }\end{array}$ \\
\hline $\begin{array}{l}\text { Personal or family history of } \\
\text { skin cancer }\end{array}$ & $\begin{array}{l}\text { - Once a person has been diagnosed with skin cancer, their risk for others is heightened. } \\
\text { - Up to } 10 \% \text { of melanoma patients will develop a second melanoma in their lifetime. } \\
\text { melanoma }\end{array}$ \\
\hline Moles (nevi) & $\begin{array}{l}\text { - Many melanomas appear to arise from pre-existing moles. } \\
\text { - Benign nevi and melanoma both frequently exhibit gain-of-function mutation in the B-Raf gene. }\end{array}$ \\
\hline Immune suppression & $\begin{array}{l}\text { - Immunosuppressive therapies (e.g. for treatment of autoimmune disorders, GVHD or rejection of solid organs in transplant } \\
\text { recipients, heightens risk for melanoma, BCC and SCC. } \\
\text { - Chemotherapy also increases risk for skin cancers. }\end{array}$ \\
\hline lonizing radiation & - Particularly for SCC. \\
\hline DNA repair deficiency & $\begin{array}{l}\text { - Xeroderma pigmentosum (XP) patients who lack one of at least eight enzymes in a common nucleotide excision repair (NER) } \\
\text { pathway have a 2,000-fold increased risk of skin cancers, including melanoma. } \\
\text { - Latency is much shorter in XP patients that in the general population, with many skin cancers developing in childhood on UV- } \\
\text { exposed skin. }\end{array}$ \\
\hline Heavy metals & $\begin{array}{l}\text { - Chromium, cobalt and other metals may promote free radical formation through Fenton chemistry, contributing to oxidative } \\
\text { mutagenesis and carcinogenesis }\end{array}$ \\
\hline
\end{tabular}

Table 1: Major risk factors for skin cancers.

of dark brown/black UV-blocking melanin pigment in the skin [16]. UV radiation in the form of ambient sunlight or artificial tanning beds is a clear risk factor for BCC, SCC and melanoma [12]. Because more UV radiation can penetrate under-melanized skin, fair-skinned individuals accrue more cancer-causing UV-induced mutations when compared with highly pigmented individuals [17]. Furthermore, pheomelanin, the red/blonde sulfated melanin pigment expressed in persons of light complexion, is a poor UV-blocker and may in fact contribute to carcinogenesis by promoting UV-mediated free radical formation [18-21].

Age: Incidence rates of BCC, SCC and melanoma all increase markedly with age (Figure 1). For BCC, incidence doubles approximately every 25 years, and is very rarely diagnosed in patients under the age of 40 years. The incidence of BCC is more than 100fold higher in people over the age of 55 years when compared to those 20 years of age or younger. The average age of diagnosis for BCC and SCC is approximately 65 years. Similarly, the average age of diagnosis for melanoma is roughly $60[14,22]$. The reason(s) why skin cancer incidence increases with age are not clearly understood, but may reflect the typical long latency (typically decades) required for accumulation of sufficient mutations to result in carcinogenesis [23].

UV radiation: UV radiation, in the form of ambient sunlight and artificial UV sources such as tanning beds [24] is among the most important risk factors for both keratinocyte malignancies and melanoma. UV radiation and UV-induced mutagenesis are estimated to cause nearly $65 \%$ of melanomas and $90 \%$ of non-melanomatous skin cancers. Skin cancer is most prevalent in nations with large populations of fair-skinned UV-sensitive persons [25,26], and particularly in those with high levels of ambient UV radiation such as Australia, the United States, New Zealand and Europe. Within the United States, geographical factors clearly point to UV playing a major causative role in skin cancer risk. For example, the incidence of BCC is almost threefold more in Southern states compared to Northern or Midwest states [27].

The pattern of UV exposure seems to differ for keratinocyte malignancies versus melanomas. Thus, high intermittent UV exposures, especially blistering sunburns early in life, influence subsequent melanoma development [28,29] whereas chronic, cumulative UV exposure predicts keratinocyte malignancies (BCC, SCC) [30]. Most skin cancers are diagnosed in "UV-exposed" areas of the body. UV radiation can promote carcinogenesis by multiple ways. First, UV energy can directly affect nucleotides in the double helix of genomic DNA, particularly the cleavage of the 5-6 double bond of pyrimidines. When two adjacent pyrimidines undergo this change, a covalent ring structure referred to as a cyclobutane pyrimidine (thymine) dimer, can be formed. Alternatively, a pyrimidine 6-4

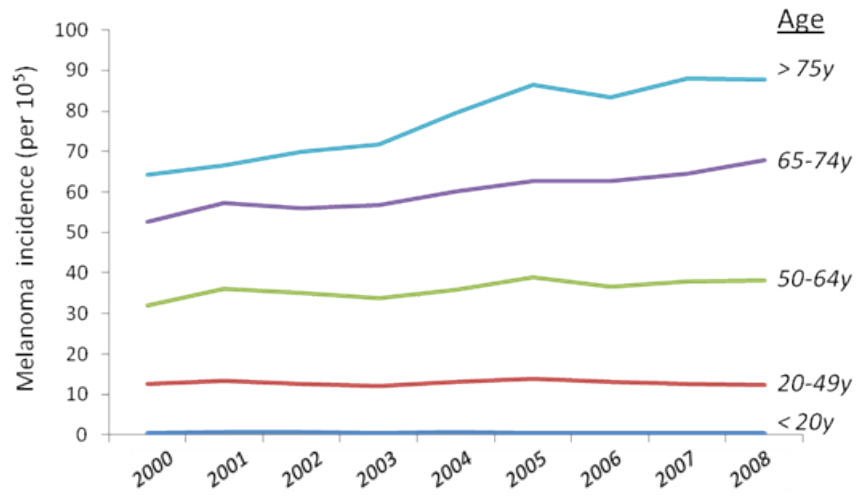

Figure 1: Melanoma incidence by age, 2000-2008, NCI SEER data. 
pyrimidone $(6,4)$ - photoproduct can result when a 5-6 double bond in a pyrimidine opens and reacts with the exocyclic moiety of the adjacent 3' pyrimidine to form a covalent 6-4 linkage [31]. In this manner, UV-induced photodimers cause characteristic "UV signature" C-T transition mutations. Molecular evidence for the contribution of UV to skin cancer comes from examining the DNA sequence of primary skin cancers. Thus, in more than half of primary BCC tumor samples, the tumor suppressor p53 is genetically altered with $65 \%$ of mutations showing characteristic UV signature mutations $(\mathrm{C}>\mathrm{T}$ or $\mathrm{CC}>\mathrm{TT}$ transitions) [32]. Similarly, $90 \%$ of SCC isolates exhibit mutations in p53, with roughly $80 \%$ showing a UV signature [33]. UV signature mutations have been found in melanoma isolates and melanoma cell lines [34,35], indicating a strong UV influence in melanoma. As a result of these and other findings, it has been estimated the great majority of skin cancers are associated with UV-induced mutagenesis [36-40]. UV radiation can also damage cells by free radical formation and oxidative stress [41]. Oxidative DNA lesions are also mutagenic and form after UV-induced free radical attack [42]. One particularly well-characterized oxidative lesion is 7,8-dihydro-8-oxoguanine (8-oxoguanine; $8-\mathrm{OH}-\mathrm{dG}$ ), which promotes mutagenesis since this guanine derivative can pair equally well with cytosine (normal pairing) and adenine (abnormal) and consequently cause GC-TA transversion mutations [43]. Thus a variety of DNA changes caused by UV radiation are potentially mutagenic. Carcinogenesis is influenced not only by the amount of environmental UV exposure but also by the degree to which damage can be repaired.

Personal or family history of skin cancer: Either because of genetic predisposition or through environmental factors, people with a personal or family history of skin cancer have a higher risk of developing cutaneous malignancy [44]. Individuals who have had melanoma once have as much as an $8 \%$ chance of developing a second primary melanoma distinct from their original tumor [45] and melanoma risk is higher in people with first-degree relatives affected by melanoma [46]. Melanoma-prone family cohorts have been described with mutations in the CDKN2A gene which encodes the p16INK4A and p14ARF tumor suppressors [47-50]. Likewise, keratinocyte malignancies occur more often in people previously diagnosed with BCC, SCC or melanoma. One study found that risk of SCC was increased up to $27 \%$ for persons previously diagnosed with BCC, and risk was 2.5 -fold higher if there was a history of prior personal melanoma [51].

Immune suppression: Individuals with defective immunity, particularly $\mathrm{T}$ cell immunity, are at increased risk for skin cancers. Thus, patients with inherited or acquired immune defects or those receiving immunosuppressive therapies (e.g. transplant recipients or cancer patients) all have a much higher risk of melanoma, BCC and SCC than normal patients [52-55]. The risk of BCC is 10-times higher and SCC up to 250-fold higher in solid organ transplant recipients [5657]. Similarly, risk of melanoma is up to eight-fold higher in the setting of immunosuppression [58]. Together, these epidemiologic studies suggest an active role for tumor immunosurveillance in resistance to skin cancers.

Other risk factors: Heavy metal exposure (such as chromium and cobalt) [59] and having a large number of moles [60] both increase risk for melanoma. Defective DNA repair, particularly nucleotide excision repair (NER) is a major risk factor for BCC, SCC and melanoma.

\section{Fair skin complexion}

People with fair-skin have a much higher lifetime risk of skin cancer than individuals with darker complexions [61]. Melanoma, for example, occurs about twenty times more frequently in fair-skinned individuals than in people with dark skin complexions $[62,63]$. Similarly, the incidences for BCC and SCC are also much higher in less-pigmented individuals, making skin pigmentation a major determinant of skin cancer. Skin pigmentation is controlled by a number of genes, often first identified in animal models with albinism or other pigmentary defects (Table 2).

Skin "color" is determined mainly by the type and amount of melanin deposited in the epidermis. Melanin is a large bio-polymer composed of subunits of different melanotic pigment species formed by sequential oxidation and cyclization of the amino acid tyrosine [64] (Figure 2). Biosynthetic reactions are catalyzed by several pigment enzymes, which when defective, render hypopigmented phenotypes. Tyrosinase is the rate-limiting enzyme that catalyzes the first two steps in melanogenesis, namely conversion of tyrosine into DOPA and then subsequently into DOPAquinone $[65,66]$. Loss of function of

\begin{tabular}{|c|c|c|c|}
\hline Gene & Function & General Structure & Pigmentation Disorder \\
\hline KITLG (stem cell factor/ kit ligand) & $\begin{array}{l}\text { Transmits survival and differentiation signals to } \\
\text { melanocytes }\end{array}$ & Membrane tyrosine kinase & Piebaldism \\
\hline MC1R (melanocortin 1 receptor) & $\begin{array}{l}\text { Binds to melanocyte stimulating hormone and } \\
\text { generates CAMP signal }\end{array}$ & 7 transmembrane Gs-coupled receptor & $\begin{array}{l}\text { Red hair, freckling, defective } \\
\text { tanning }\end{array}$ \\
\hline MITF (microphthalmia) & $\begin{array}{l}\text { Myc-like master transcription factor essential for } \\
\text { melanocyte differentiation and survival }\end{array}$ & $\begin{array}{l}\text { basic-helix-loop-helix-leucine-zipper } \\
\text { transcription factor }\end{array}$ & $\begin{array}{l}\text { Waardenburg syndrome } \\
\text { type } 2\end{array}$ \\
\hline OA1 receptor & Maintenance of melanosome size & G-protein-coupled receptor & Ocular albinism (OA) \\
\hline P/OCA2 & Melanosome acidification & $\begin{array}{l}\text { 12-transmembrane domain-containing } \\
\text { protein }\end{array}$ & $\begin{array}{l}\text { Oculocutaneous albinism type } \\
2 \text { (OCA2) }\end{array}$ \\
\hline Pmel17 (gp100; ME20) & Striation formation; melanin polymerization & Type 1 transmembrane protein & Unknown \\
\hline $\begin{array}{l}\text { SLC24A5 (solute carrier family } 24 \\
\text { member } 5 \text { ) }\end{array}$ & Melanosomal cation exchange & Membrane transporter & Fair skin \\
\hline TRP1 (tyrosinase-related protein-1) & Melanin biosynthesis; tyrosinase stabilization & Type 1 transmembrane protein & $\begin{array}{l}\text { Oculocutaneous albinism type } \\
3 \text { (OCA3) }\end{array}$ \\
\hline TRP2 (dopachrome tautomerase) & Melanin biosynthetic enzyme & Type 1 transmembrane protein & Unknown \\
\hline TYR (tyrosinase) & Rate-limiting enzyme in melanin biosynthesis & Type I transmembrane protein & $\begin{array}{l}\text { Oculocutaneous albinism type } \\
1 \text { (OCA } 1)\end{array}$ \\
\hline
\end{tabular}

Table 2: Major genes affecting skin color [1-7] 


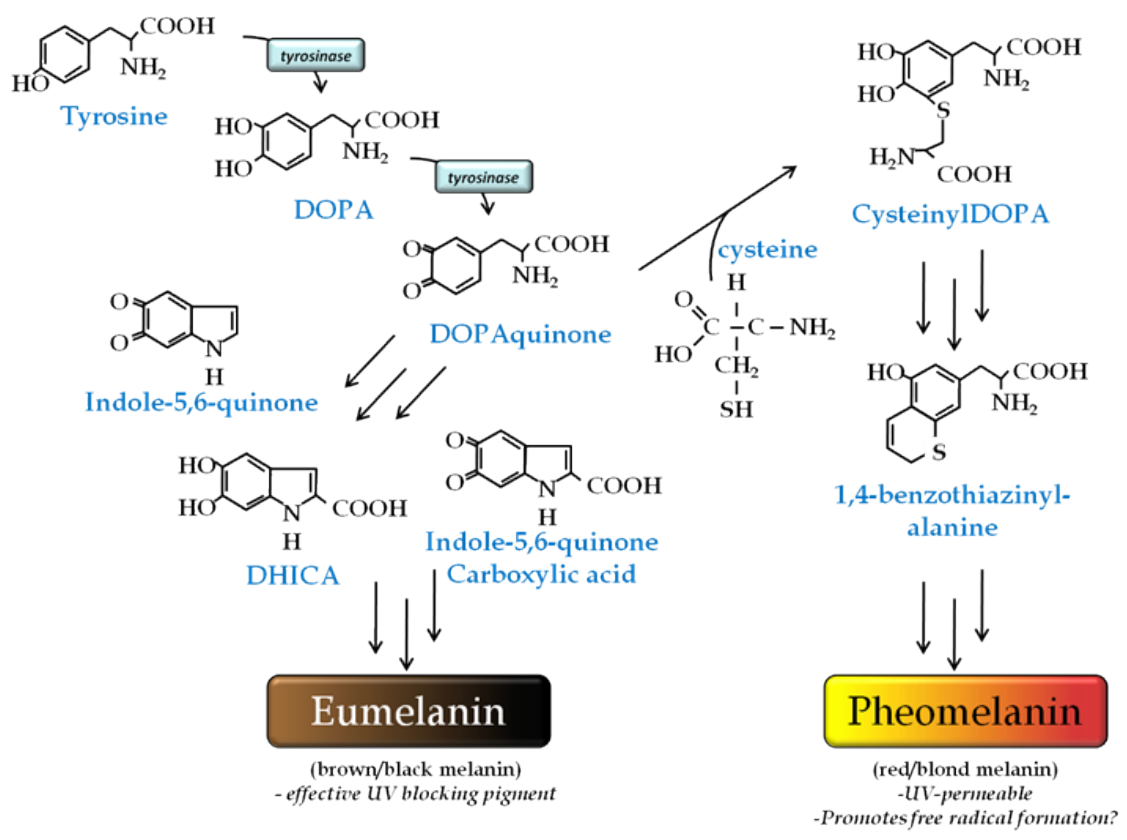

Figure 2: Melanin Biosynthesis. Melanins are large bioaggregates composed of pigmented precursors originally derived from the amino acid tyrosine. Epidermal melanins are present in two major forms: (1) eumelanin, an effective UV-blocking brown/black pigment and (2) pheomelanin, a sulfur-containing red/blonde pigment less able to absorb UV photons. The melanocyte stimulating hormone (MSH) - melanocortin 1 receptor (Mc1r) signaling axis is a major determinant of the type and amount of melanin produced by melanocytes in the skin.

\begin{tabular}{|c|c|c|c|c|c|}
\hline $\begin{array}{l}\text { Fitzpatrick } \\
\text { Phototype }\end{array}$ & Phenotype & $\begin{array}{l}\text { Epidermal } \\
\text { eumelanin }\end{array}$ & UV Response & $\begin{array}{c}\text { MED } \\
\left(\mathrm{mJ} / \mathrm{cm}^{2}\right)^{*}\end{array}$ & Skin cancer risk \\
\hline I & $\begin{array}{l}\text { - Basal skin tone is bright white } \\
\text { - Northern European/British }\end{array}$ & $+/-$ & $\begin{array}{l}\text { - Always burns, peels } \\
\text { - Never tans }\end{array}$ & $15-30$ & ++++ \\
\hline II & $\begin{array}{l}\text { - Basal skin tone is white } \\
\text { - European/Scandinavian }\end{array}$ & + & $\begin{array}{l}\text { - Burns easily, peels } \\
\text { - Tans minimally }\end{array}$ & $25-40$ & $+++/++++$ \\
\hline III & $\begin{array}{l}\text { - Basal skin tone is fair } \\
\text { - Southern or Central European }\end{array}$ & ++ & $\begin{array}{l}\text { - Burns moderately } \\
\text { - Average tanning }\end{array}$ & $30-50$ & +++ \\
\hline IV & $\begin{array}{l}\text { - Basal skin tone is light brown } \\
\text { - Mediterranean, Asian or Latino }\end{array}$ & +++ & $\begin{array}{l}\text { - Burns minimally } \\
\text { - Tans easily }\end{array}$ & $40-60$ & ++ \\
\hline $\mathbf{v}$ & $\begin{array}{l}\text { - Basal skin tone is brown } \\
\text { - East Indian, Native American, Latino or } \\
\text { African }\end{array}$ & ++++ & $\begin{array}{l}\text { - Rarely burns } \\
\text { - Tans easily }\end{array}$ & $60-90$ & + \\
\hline VI & $\begin{array}{l}\text { - Basal skin tone is black } \\
\text { - African or Aboriginal ancestry }\end{array}$ & ++++++ & $\begin{array}{l}\text { - Almost never burns } \\
\text { - Tans readily }\end{array}$ & $90-150$ & $+/-$ \\
\hline
\end{tabular}

Minimal erythematous dose (MED) is the least amount of UV that will result in sunburn $24 \mathrm{~h}$ after exposure

Table 3: Fitzpatrick Scale of Skin Phototypes

tyrosinase is the defect in the most common type of human albinism. In the skin, melanin is synthesized in melanocytes and then transferred to keratinocytes where it accumulates to protect the skin against UV injury [67]. There are two basic types of melanin: eumelanin and pheomelanin [68]. Eumelanin is a far better "sunscreen" than pheomelanin. After a common biosynthetic pathway mediated by tyrosinase, eumelanin and pheomelanin synthesis diverge after the formation of dopaquinone (Figure 2). Eumelanin is preferentially expressed in UV-protected people with dark complexions. It is chemically inert, poorly-soluble and quite efficient at absorbing UV photons. In contrast, pheomelanin is the melanin preferentially expressed in UV-and skin cancer-prone individuals of light complexion. Due to incorporation of cysteine into its precursors, pheomelanin is a red-yellow sulfur-containing compound [69]. UV resistance is mainly determined by the levels of eumelanin found in the epidermis [70]. Besides allowing more UV energy to pass through the superficial layers of the epidermis to cells in the basal layer, pheomelanin may actually contribute to UV-induced free radical formation and oxidative DNA damage in the skin [71-73]. The contribution of pheomelanin to UV-induced carcinogenesis is an ongoing area of investigation.

Accounting for $5-10 \%$ of cells in the basal layer of the epidermis, melanocytes are dendritic-type cells derived from the neural crest. They are the sole manufacturers of melanin in the skin. Each epidermal melanocyte may be in intimate contact with as many as 30-50 maturing keratinocytes in what has been termed the "epidermal melanin unit" [74]. As pigment is manufactured, melanocytes actively transfer melanin to neighboring keratinocytes. In this manner, melanin accumulates in the epidermis to function as a "natural sunscreen" to protect the skin against UV radiation [75].

Skin complexion can be described using the "Fitzpatrick Scale" which describes individual phototypes by basal skin complexion and 
Citation: Christian P, Vanover J, Scott T, Tullo G, D’Orazio JA (2011) Epidermal Pigmentation, Nucleotide Excision Repair and Risk of Skin Cancer. J Carcinogene Mutagene S4:001. doi:10.4172/2157-2518.S4-001

UV sensitivity [76-78] (Table 3). Persons of very light complexion are described as being "phototype I" whereas those of the very darkest complexions are "phototype VI". Skin cancer incidence is highest among persons of low Fitzpatrick phototype who are relatively undermelanized and who burn rather than tan in response to UV exposure. Minimal erythematous dose, often abbreviated "MED", is a measure of the skin's response to ultraviolet radiation using erythema (redness, swelling) as an endpoint. More UV radiation is needed to "burn" dark skin, and therefore MED is higher in dark-skinned persons $[76,79,80]$. Most of the genes associated with pigmentation encode protein products that influence melanocyte differentiation/ survival, pigment biosynthesis or melanin localization/transport [2]. In general, defects in melanin biosynthetic enzymes lead to incomplete loss of pigmentation whereas those that result in failures in melanocyte development result in more profound phenotypes. Overall, it seems that the protein products of several genes together influence basal skin pigmentation in humans.

\section{Adaptive pigmentation and the melanocortin 1 receptor (MC1R)}

A prominent feature of fair-skinned cancer-prone individuals is their tendency to burn rather than tan after UV exposure. The ability to increase levels of epidermal melanin after a first UV insult is physiologically critical to reducing subsequent UV damage. The melanocortin 1 receptor (MC1R) has emerged as a critical determinant of pigmentation and the tanning response. With respect to skin cancer, loss of function mutations of MC1R are a well-described risk factor for melanoma $[61,81]$ and MC1R signaling seems to be central to the adaptive tanning response (Figure 3 ). The MC1R is a seventransmembrane G-protein-coupled receptor that upon binding to a-melanocyte stimulating hormone (MSH), activates adenylate cyclase and formation of the second messenger cAMP. This signaling cascade initiates a series of pro-survival and pro-differentiation molecular events, including up-regulation of eumelanin production [82]. When MC1R signaling is defective, then there is limited ability to upregulate melanin production after UV exposure. Among humans, there are three clinically-relevant common polymorphisms of the MC1R: Arg151Cys (R151C), Arg160Trp (R160W) and Asp294His (D294H). These "red hair color" (RHC) variants correlate with red hair, freckling and tendency to burn rather than tan after UV exposure. Molecularly, the RHC MC1R variants display a muted ability to activate adenylate cyclase after MSH binding, and thus are associated with a blunted cAMP signaling response. Importantly, these loss-offunction polymorphisms of MC1R are also influence susceptibility to melanoma and other skin cancers. Using an animal model, we showed that functional Mclr signaling is critical to adaptive pigmentation. Whereas mice with intact Mclr responded to repeated UV exposure by depositing eumelanin in the epidermis, animals that were genetically

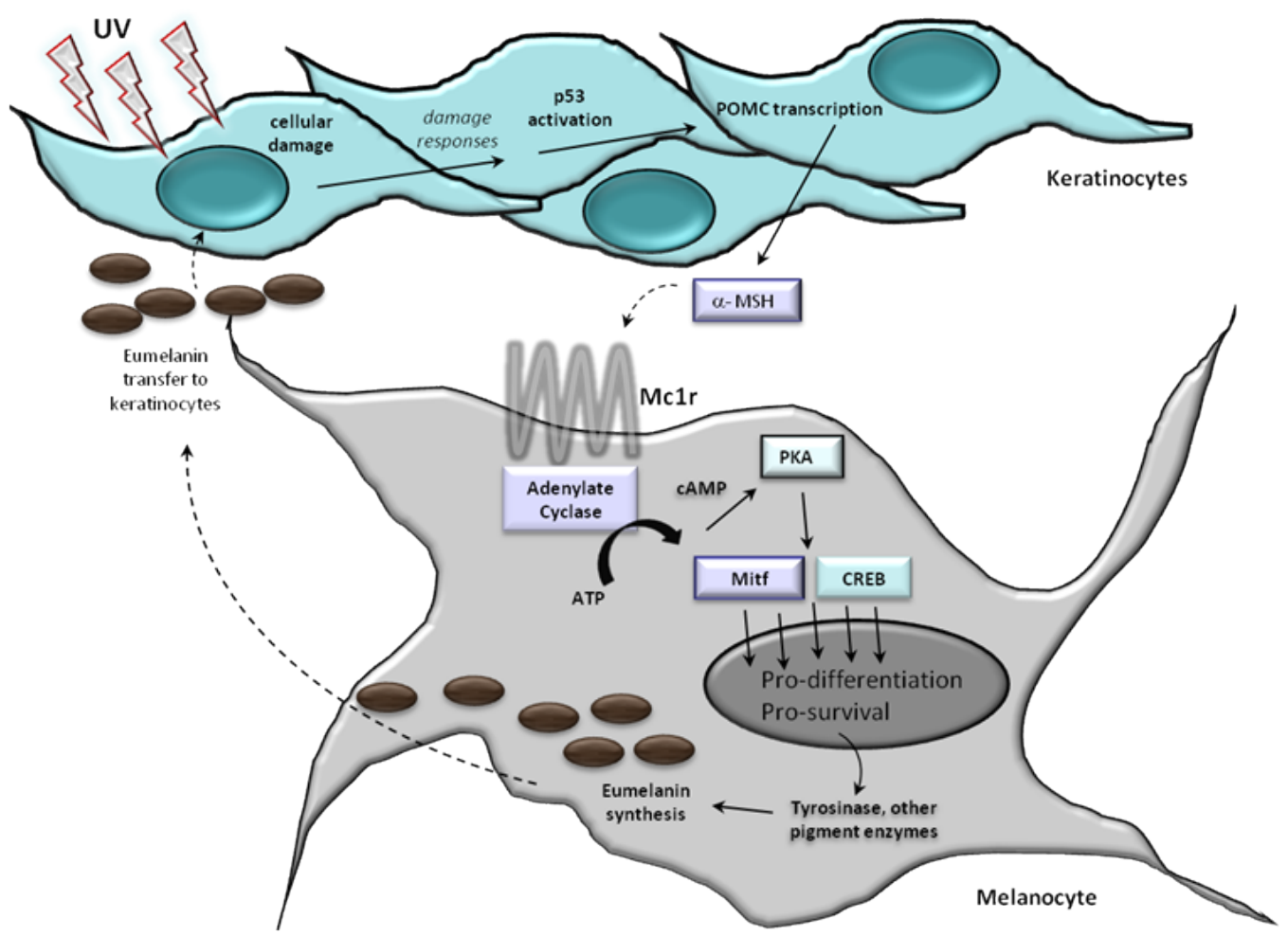

Figure 3: The adaptive tanning response. Adaptive pigmentation, or the ability to make a protective tan after sun exposure, is dependent on both p53 and the melanocortin 1 receptor (MC1R) [8-9]. UV-induced damage in keratinocytes induces p53-mediated up-regulation of transcriptional expression of the proopiomelanocortin (POMC) gene. The POMC gene encodes a propeptide whose cleavage products include a-melanocyte stimulating hormone (MSH), the cognate ligand of the melanocortin 1 receptor (MC1R) on melanocytes. MSH produced and secreted from UV-exposed keratinocytes binds to MC1R on melanocytes in the basal epidermis, inducing adenylyl cyclase activation and generation of the second messenger cAMP. Elevated cAMP levels trigger a number of downstream events including activation of protein kinase A (PKA) and subsequent up-regulation of two transcription factors- the cAMP responsive binding element (CREB) and microphthalmia (Mitf)- that both mediate up-regulation of melanin production by induction of tyrosinase and other melanogenic enzymes. Thus, MSH-MC1R signaling leads to enhanced pigment synthesis and subsequent transfer of melanin to epidermal keratinocytes. As a result, the skin is more protected against subsequent UV insults. It is likely that UV radiation also has direct, cell-autonomous effects on melanocytes. 
identical except for loss of Mc1r failed to melanize at all in response to the UV exposure [8]. In subsequent work, Cui and colleagues found that adaptive pigmentation was dependent on p53 function [9]. Thus, we hypothesize that the ability to tan adaptively after UV exposure involves a p53-mediated MSH-MC1R-dependent signaling pathway in the epidermis (Figure 3) and that defects in this pathway predispose individuals to UV sensitivity and UV-induced skin cancers. People with a defective "tanning response" and fair skin are prone to the accumulation of UV-induced mutations in the skin by having insufficient melanin to interfere with UV penetration.

\section{Nucleotide Excision Repair (NER)}

Risk of developing skin cancer is related both to UV exposure as well as the extent to which an individual is able to recover from UV-mediated cellular injury. The major DNA repair pathway that reverses UV-induced photolesions (e.g. cyclobutane dimers, $[6,4]$-photoproducts) is the nucleotide excision repair (NER) pathway, which involves multiple proteins and the following basic steps:

Recognition of damage and recruitment of a multi-protein repair complex to the damaged site.

Nicking the damaged strand several nucleotides away on each side of the damaged site and excision of the damaged region between the two nicks.

Filling in the resultant gap by a DNA polymerase using the nondamaged strand as a template and ligating the final nick to seal the strand.

The process of NER begins with the recruitment and binding of the XPC/HHR23B complex to sites of DNA damage that distort the normal structure of the double helix [83-85]. NER can be broken down into two types, depending on how the initial damage is identified. If the damage is present in an actively transcribed gene, then "transcriptioncoupled repair" (TC-NER) may be initiated because of interference (by the DNA lesion) with the normal function of RNA polymerases and other transcription proteins [86]. Transcription-coupled repair is initiated through the involvement of the CSA and CSB proteins, which are defective in Cockayne syndromes. These NER proteins facilitate removal of stalled RNA polymerases and entry of NER machinery in order that the DNA damage may be repaired [87]. If, however, the damage is located in non-transcribed sections of the genome, then NER is initiated through "global genome repair" (GG-NER) in a process that does not involve the CS proteins. Rather, GG-NER surveillance is accomplished via a heterodimeric complex composed of XPC and HR23B [88]. The XPC-HR23B protein complex, perhaps in conjunction with DDB1 and DDB2 (XPE), binds to sites of helicaldistorting DNA damage (such as the photolesions produced by UV radiation) and recruits other NER proteins to the damaged area [8990]. The next step in NER is thought to involve local unwinding of the double helix around the damage, mediated by the TFIIH complex which is a multiprotein complex comprised of at least nine subunits, including the XPB and XPD helicases which function 3' to 5' and 5' to 3 ' respectively [91]. In this manner, TFIIH unwinds a stretch of 2030 nucleotides that include and surround the damaged nucleotides. In this manner, there is local relaxing of three-dimensional structure in order to optimize function and access for subsequent NER proteins [92,93]. Two enzymes - XPA and RPA- stabilize the unwound DNA surrounding the area of damage to protect the separated strands from further chemical or enzymatic attack (e.g. strand breaks) during the repair process $[89,94]$. The next step in NER involves cleaving the damaged strand of DNA, mediated by the XPF and XPG endonucleases [95]. XPF functions in a heterodimeric complex with ERCC1 to nick the DNA $20( \pm 5)$ nucleotides 5' downstream of the damage while XPG cleaves $5( \pm 3)$ nucleotides 3 ' to the damage [96-101]. Once the damaged strand has been nicked on either side of the lesion, the damaged piece (typically 20-30 nucleotides in length) is displaced along with the TFIIH-XPA-XPG-XPF/ERCC1 complex to leave an undamaged, unpaired complementary strand which will serve as the template to restore the previously damaged area of the genome [102]. The gap is restored through the actions of RPA, RF-C, PCNA and DNA polymerase $\delta$ and $\varepsilon$ using the opposite undamaged strand as a template [103]. Finally, DNA ligase seals the newly-synthesized oligomer to the remainder of the DNA [89,90,104-106].

The importance of NER can clearly be demonstrated by observing the natural history of Xeroderma pigmentosum (XP), a clinical condition of homozygous deficiency of any one of at least eight enzymes (XPA-G) central to the NER pathway $[107,108]$. XP patients suffer lifelong extreme sensitivity to UV radiation and are among the highest risk patients for all types of UV-induced skin cancers (including melanoma). Thus, individuals with XP suffer severe and disfiguring UV-induced skin changes, and have a greatly increased (>1000-fold) incidence of skin cancers, often with their first skin cancer arising during childhood. Skin malignancies from XP patients show a high frequency of UV-induced p53 mutations [109]. Many XP patients die in young adulthood from skin cancer (often melanoma). Intriguingly, polymorphisms that result in incomplete but not total loss of NER function may predict increased carcinogenesis in the general population [110-117].

\section{Regulation of nucleotide excision repair (NER)}

At least eight enzymes- XPA, ERCC3 (XPB), XPC, ERCC2 (XPD), DDB2 (XPE), ERCC4 (XPF), ERCC5 (XPG), and POLH (XP-V)- work in concert to carry out nucleotide excision DNA repair. Homozygous lack of any one of the NER enzymes causes the disease xeroderma pigmentosum (XP) which is characterized by profound UV-sensitivity and exorbitant risk of skin cancer [118]. XP, being an autosomal recessive disorder, is very rare, however there is emerging evidence that hypomorphic polymorphisms in the NER response occur among the general population and that these may influence melanoma and skin cancer risk $[119,120]$. Individuals with more proficient NER would theoretically be more protected against UV-induced malignancy, and the contribution of NER polymorphisms in risk of skin cancer is an area of active investigation [121-123]. Recently, somatic loss of NER through acquired XPC inactivation was shown to occur in a significant number of human squamous cell carcinomas, suggesting that loss-offunction of NER may actually be pivotal to skin cancer progression [124]. Nucleotide excision DNA repair involves the following basic steps: (1) damage surveillance and recognition, (2) recruitment of NER proteins to the site of DNA damage, (3) nicking the affected strand on either side of the lesion and excision of the damaged region between the two nicks and (4) filling in the resultant gap by a DNA polymerase using the non-damaged strand as a template and ligating the final nick to seal the strand.

Mechanisms regulating NER is a very active area of investigation; there are many potential points in the NER pathway wherein the efficiency of NER could be modified. Recognition of DNA damage during GG-NER requires the recruitment of damage specific DNAbinding proteins. Zhao and colleagues recently reported that NER activity could be regulated by MAP kinase pathway-mediated 
heterochromatin structure. Specifically, they found that inhibiting p38 in UV-irradiated normal human fibroblasts resulted in reduced chromatin relaxation, reduced DDB2 ubiquitination, and decreased $\mathrm{XPC}$ recruitment to CPDs and concluded that $\mathrm{p} 38$ is a major player in DNA damage recognition by regulating chromatin relaxation and DDB2 degradation [125]. XPC is recruited to the DNA damage site very early and is thought to be a critical initiator of GG-NER [84,125-127]. DDB2, a component of the larger UV-DDB complex, is also recruited to DNA lesions independent of XPC binding [125,128]. Following UV-irradiation, UV-DDB recognizes the DNA lesion and aids in the recruitment XPC [129]. DDB2 is then ubiquitinated allowing XPC to bind the damage site and initiate NER [130-132]. This process is much more important for repair of DNA damage within chromatin. XPC localization is dependent on DDB2 levels. In p53 null cells with low basal levels of DDB2, XPC localized to DNA damage sites much more slowly than in cells overexpressing DDB2 [127]. Further, XPC was unable to bind CPDs unless DDB2 was present [126]. Thus p53 can regulate DNA damage site recognition by modulating DDB2 enzyme transcription.

There is evidence that the damage recognition step can be variable. One of the most well studied mammalian cellular responses to DNA damage involves the p53 tumor suppressor gene. p53 was first implicated in genomic repair n 1995 when UVC exposed fibroblasts containing mutated p53 displayed a decreased capacity to repair cyclobutane pyrimidine dimers (CPDs) as compared to wild type p53 fibroblasts [133]. This p53 mediated NER effect was later found to be specific for GG-NER, while transcription-coupled repair was not affected by p53 status [134-136], suggesting that p53's involvement in NER may be limited to the initial damage recognition steps. In later studies, p53 was found to have a profound effect on CPD clearance but little influence on the repair of 6-4PP [137,138]. Initially, studies on p53-mediated regulation of NER were focused on p53's ability to induce transcription of NER associated genes. Interestingly, a number of UV-inducible genes, namely MDM2, XPC and DDB2, are known p53 transcriptional targets: [139]. XPC and DDB2 were first reported to be under the transcriptional control of p53 in 2002 and later found to be induced in a DNA damage-dependent manner $[140,141]$. The key NER enzyme DDB2, part of the UV-damaged DNA binding complex (UVDDB), has also been shown to be regulated at the post-translational level. This complex has high affinity for UV-induced DNA lesions, especially 6-4PPs, and binds lesions quickly after UV insult. After UV irradiation, the UV-DDB subunit DDB2 is rapidly polyubiquitinated via association with its binding partner DDB1 and its ability to bind Cullin 4A, an E3 ubiquitin ligase. Once ubiquitinated, DDB2 degradation reveals the DNA lesion and allows for the recruitment and binding of XPC to the DNA damage sites, an event essential for NER activation. [84,132,142,143].

XPC, a critical mediator of NER, is itself regulated by p53 [140] and has recently been reported to be influenced by promoter methylation [144] and PTEN through AKT/p38 signaling [145]. XPC can itself regulate levels and nuclear localization of CENTRIN 2, a microtubule nucleating proteins localized to centrosomes that may regulate mRNA transport out of the nucleus. [146,147]. XPC enzyme levels may be regulated by efficiency of proteosomal degradation $[148,149]$. Smith and coworkers found that MG-132, a ubiquitin ligase inhibitor, blocked XPC degradation and that unphosphorylated RB protein stabilized XPC and enhanced NER [150].
Sancar and colleagues recently reported that XPA may be the ratelimiting factor of NER function, that it is transcriptionally regulated by a molecular circadian rhythm, that it undergoes post-translational acetylation and that XPA enzyme levels were regulated in part by ubiquitination by the E3 ubiquitin ligase HERC2 and subsequent degradation by the $26 \mathrm{~S}$ proteasome [151]. Historically, the role of MAP kinase pathways including JNKs, ERKs, and p38 MAPK in NER function has been controversial [152-156]. However, recently a study by Zhao and colleagues provides insight into a p38 driven mechanism of NER activation. They found that inhibiting p38 in UV-irradiated normal human fibroblasts resulted in reduced chromatin relaxation, reduced DDB2 ubiquitination, and decreased XPC recruitment to CPDs and concluded that p38 plays a major role in DNA damage recognition by regulating chromatin relaxation and DDB2 degradation [125]. Thus, it appears that NER efficiency (and ultimately rates of mutagenesis and carcinogenesis) can be influenced by the efficiency by which DNA damage is recognized, the levels and stability of NER enzyme mRNA and proteins, their nuclear localization, and their enzymatic activity. Clearly there are numerous ways in which cells may modify NER activity.

\section{$M C 1 R$ and DNA repair}

In melanocytes, it appears that NER can be regulated by MC1R signaling and the cAMP second messenger pathway. Using human melanocytes transfected with $M c 1 r$ genes of variable functionality, various groups have reported a reproducible link between MC1RcAMP signaling and NER efficiency [157-160]. Using our MC1Rvariant C57BL/6 murine model, we also observed that the clearance of UV-induced thymine dimers in the skin of Mclr-defective mice was compromised (Figure 4). We and others are currently investigating the molecular mechanisms linking Mclr signaling with NER activity. Pharmacologic manipulation of melanocytic cAMP levels represents a promising and novel approach to alter UV sensitivity and melanoma risk. Pharmacologic MC1R mimetics include both small peptides that mimic MSH agonist activity [161] as well as agents that bypass the MC1R to directly manipulate melanocyte cAMP levels. We, for example, reported that topical application of forskolin, a skin-permeable small molecule that directly adenylate cylase restored dark pigmentation in an Mclr-defective animal model and that this induced melanin was potently protective against UV damage and carcinogenesis of the skin [8]. We posit that this approach may also enhance NER in the skin.

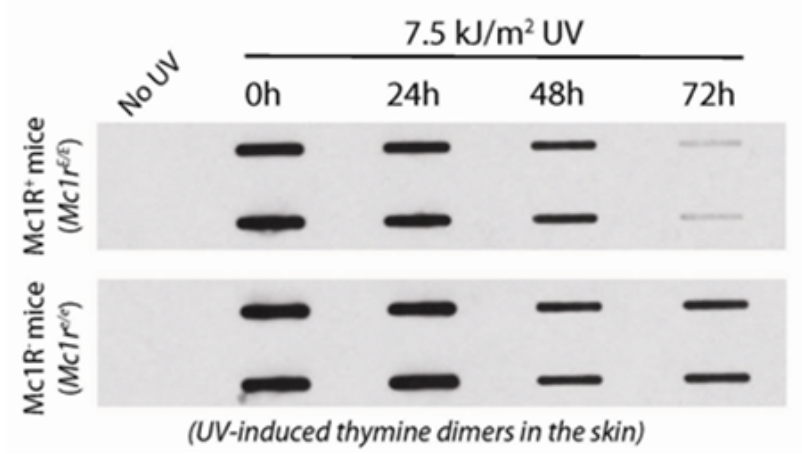

Figure 4: Mc1r function influences repair of UV-induced DNA damage. Mc1r-intact (Mc1 $\mathrm{r}^{\mathrm{E} / \mathrm{E}}$ ) or-defective $\left(\mathrm{Mc}^{\mathrm{r}} \mathrm{r}^{\mathrm{e} / \mathrm{e}}\right.$ ) mice were exposed to UV. Clearance of thymine dimers in the skin was followed over time by Southwestern analysis using a monoclonal antibody against thymine dimers. Note that animals with intact $\mathrm{Mc} 1 \mathrm{r}$ cleared thymine dimers more efficiently than Mc1r-defective mice. 
Citation: Christian P, Vanover J, Scott T, Tullo G, D'Orazio JA (2011) Epidermal Pigmentation, Nucleotide Excision Repair and Risk of Skin Cancer J Carcinogene Mutagene S4:001. doi:10.4172/2157-2518.S4-001

Page 8 of 11

\section{Conclusions}

The incidence and morbidity of both non-melanomatous skin cancers and malignant melanoma have increased dramatically over the past several decades. By understanding the mechanisms of carcinogenesis as well as innate mechanisms of resistance to carcinogenesis, rational preventive strategies can be developed to reduce the burden of disease caused by skin cancers. One of the most important genetic loci that influences skin cancer risk is the MC1R which is characterized by demonstrating defective signaling polymorphisms in skin cancer prone, fair-skinned populations. Besides regulating adaptive pigmentation (tanning), MC1R signaling also induces more efficient nucleotide excision repair. Defective MC1R signaling not only permits increased UV penetration into the skin because of a pigment defect, but it is also associated with sluggish NER which favors UV-induced mutagenesis. Our long-term goal is to devise rational pharmacologic strategies to rescue MC1R signaling in highrisk cancer-prone populations in order to reduce risk of melanoma and other skin cancers.

\section{References}

1. Marks MS, Seabra MC (2001) The melanosome: membrane dynamics in black and white. Nat Rev Mol Cell Biol 2: 738-748.

2. Parra EJ (2007) Human pigmentation variation: evolution, genetic basis, and implications for public health. Am J Phys Anthropol Suppl 45: 85-105.

3. Inagaki K, Suzuki T, Ito S, Suzuki N, Adachi K, et al. (2006) Oculocutaneous albinism type 4: six novel mutations in the membrane-associated transporter protein gene and their phenotypes. Pigment Cell Res 19: 451-453.

4. Newton JM, Cohen-Barak O, Hagiwara N, Gardner JM, Davisson MT, et al. (2001) Mutations in the human orthologue of the mouse underwhite gene (uw) underlie a new form of oculocutaneous albinism, OCA4. Am J Hum Genet 69 : 981-988.

5. Edwards M, Bigham A, Tan J, Li S, Gozdzik A, et al. (2010) Association of the OCA2 polymorphism His615Arg with melanin content in east Asian populations: further evidence of convergent evolution of skin pigmentation. PLoS Genet 6: e1000867.

6. Sturm RA (2009) Molecular genetics of human pigmentation diversity. Hum Mol Genet 18: 9-17.

7. Scherer D, Rachakonda PS, Angelini S, Mehnert F, Sucker A, et al. (2010) Association between the germline MC1R variants and somatic BRAF/NRAS mutations in melanoma tumors. J Invest Dermatol 130: 2844-2848.

8. D'Orazio JA, Nobuhisa T, Cui R, Arya M, Spry M, et al. (2006) Topical drug rescue strategy and skin protection based on the role of Mc1r in UV-induced tanning. Nature 443: 340-344.

9. Cui R, Widlund HR, Feige E, Lin JY, Wilensky DL, et al. (2007) Central role of p53 in the suntan response and pathologic hyperpigmentation. Cell 128: 853-864.

10. Society AC: Cancer Facts \& Figures 2011. In. Atlanta: American Cancer Society; 2011: 1-58.

11. Miller DL, Weinstock MA (1994) Nonmelanoma skin cancer in the United States: incidence. J Am Acad Dermatol 30: 774-778.

12. Linos E, Swetter SM, Cockburn MG, Colditz GA, Clarke CA (2009) Increasing burden of melanoma in the United States. J Invest Dermatol 129: 1666-1674.

13. Erickson C, Driscoll MS (2010) Melanoma epidemic: Facts and controversies. Clin Dermatol 28: 281-286.

14. SEER Stat Fact Sheets: Melanoma of the Skin.

15. Cho E, Rosner BA, Feskanich D, Colditz GA (2005) Risk factors and individual probabilities of melanoma for whites. J Clin Oncol 23: 2669-2675.

16. Garbe C, Leiter U (2009) Melanoma epidemiology and trends. Clin Dermatol 27: 3-9.
17. Veierod MB, Adami HO, Lund E, Armstrong BK, Weiderpass E (2010) Sun and solarium exposure and melanoma risk: effects of age, pigmentary characteristics, and nevi. Cancer Epidemiol Biomarkers Prev 19: 111-120.

18. Smit NP, van Nieuwpoort FA, Marrot L, Out C, Poorthuis B, et al. (2008) Increased Melanogenesis is a Risk Factor for Oxidative DNA Damage- Study on Cultured Melanocytes and Atypical Nevus Cells. Photochem Photobiol 84 550-555.

19. Abdel-Malek ZA, Knittel J, Kadekaro AL, Swope VB, Starner R (2008) The melanocortin 1 receptor and the UV response of human melanocytes--a shift in paradigm. Photochem Photobiol 84: 501-508.

20. Kadekaro AL, Wakamatsu K, Ito S, Abdel-Malek ZA (2006) Cutaneous photoprotection and melanoma susceptibility: reaching beyond melanin content to the frontiers of DNA repair. Front Biosci 11: 2157-2173.

21. Kvam E, Tyrrell RM (1999) The role of melanin in the induction of oxidative DNA base damage by ultraviolet A irradiation of DNA or melanoma cells. J Invest Dermatol 113: 209-213.

22. Dennis LK (1999) Analysis of the melanoma epidemic, both apparent and real: data from the 1973 through 1994 surveillance, epidemiology, and end results program registry. Arch Dermatol 135: 275-280.

23. Liu T, Soong SJ (1996) Epidemiology of malignant melanoma. Surg Clin North Am 76: 1205-1222.

24. Lim HW, James WD, Rigel DS, Maloney ME, Spencer JM, et al. (2011) Adverse effects of ultraviolet radiation from the use of indoor tanning equipment: Time to ban the tan. J Am Acad Dermatol 64: 893-902.

25. Rigel DS (2010) Epidemiology of melanoma. Semin Cutan Med Surg 29: 204 209.

26. Tucker MA (2009) Melanoma epidemiology. Hematol Oncol Clin North Am 23: 383-395.

27. Marks R (2000) Epidemiology of melanoma. Clin Exp Dermatol 25: 459-463.

28. MacKie RM, Aitchison T (1982) Severe sunburn and subsequent risk of primary cutaneous malignant melanoma in scotland. $\mathrm{Br} \mathrm{J}$ Cancer 46: 955-960.

29. Gandini S, Sera F, Cattaruzza MS, Pasquini P, Abeni D, et al. (2005) Metaanalysis of risk factors for cutaneous melanoma: I. Common and atypical naevi. Eur J Cancer 41: 28-44.

30. Leiter U, Garbe C (2008) Epidemiology of melanoma and nonmelanoma skin cancer--the role of sunlight. Adv Exp Med Biol 624: 89-103.

31. Sarasin A (1999) The molecular pathways of ultraviolet-induced carcinogenesis Mutat Res 428: 5-10

32. Soehnge $H$, Ouhtit A, Ananthaswamy ON (1997) Mechanisms of induction of skin cancer by UV radiation. Front Biosci 2: 538-551.

33. Wikonkal NM, Brash DE (1999) Ultraviolet radiation induced signature mutations in photocarcinogenesis. J Invest Dermatol 4: 6-10.

34. Greenman C, Stephens P, Smith R, Dalgliesh GL, Hunter C, et al. (2007) Patterns of somatic mutation in human cancer genomes. Nature 446: 153-158.

35. Pleasance ED, Cheetham RK, Stephens PJ, McBride DJ, Humphray SJ, et al (2010) A comprehensive catalogue of somatic mutations from a human cancer genome. Nature 463: 191-196.

36. Giglia-Mari G, Sarasin A (2003) TP53 mutations in human skin cancers. Hum Mutat 21: 217-228.

37. Trappey A, Fernando A, Gaur R, Raj M, Ouhtit A (2010) The shady side of sunlight: current understanding of the mechanisms underlying UV-induction of skin cancers. Front Biosci (Schol Ed) 2: 11-17.

38. Narayanan DL, Saladi RN, Fox JL (2010) Ultraviolet radiation and skin cancer Int J Dermatol 49: 978-986.

39. Afaq F (2011) Natural agents: cellular and molecular mechanisms of photoprotection. Arch Biochem Biophys 508: 144-151.

40. Weinstock MA, Fisher DE (2010) Indoor ultraviolet tanning: what the data do and do not show regarding risk of melanoma and keratinocyte malignancies. $J$ Natl Compr Canc Netw 8: 867-873.

41. Hoeijmakers JH (2009) DNA damage, aging, and cancer. N Engl J Med 361 1475-1485. 
Citation: Christian P, Vanover J, Scott T, Tullo G, D'Orazio JA (2011) Epidermal Pigmentation, Nucleotide Excision Repair and Risk of Skin Cancer J Carcinogene Mutagene S4:001. doi:10.4172/2157-2518.S4-001

42. Meyskens FL Jr, Farmer P, Fruehauf JP (2001) Redox regulation in human melanocytes and melanoma. Pigment Cell Res 14: 148-154.

43. Schulz I, Mahler HC, Boiteux S, Epe B (2000) Oxidative DNA base damage induced by singlet oxygen and photosensitization: recognition by repair endonucleases and mutagenicity. Mutat Res 461: 145-156.

44. Bergstresser PR, Halprin KM (1975) Multiple sequential skin cancers. The risk of skin cancer in patients with previous skin cancer. Arch Dermatol 111: 995996.

45. Ferrone CR, Ben Porat L, Panageas KS, Berwick M, Halpern AC, et al. (2005) Clinicopathological features of and risk factors for multiple primary melanomas. Jama 294: 1647-1654

46. Gandini S, Sera F, Cattaruzza MS, Pasquini P, Picconi O, et al. (2005) Metaanalysis of risk factors for cutaneous melanoma: II. Sun exposure. Eur J Cancer 41: 45-60.

47. Hansson J (2010) Familial cutaneous melanoma. Adv Exp Med Biol 685: 134 145.

48. Meyle KD, Guldberg P (2009) Genetic risk factors for melanoma. Hum Genet 126: $499-510$.

49. Kamb A, Shattuck-Eidens D, Eeles R, Liu Q, Gruis NA, et al. (1994) Analysis of the p16 gene (CDKN2) as a candidate for the chromosome 9p melanoma susceptibility locus. Nat Genet 8: 23-26.

50. Hussussian CJ, Struewing JP, Goldstein AM, Higgins PA, Ally DS, et al. (1994) Germline p16 mutations in familial melanoma. Nat Genet 8: 15-21.

51. Cantwell MM, Murray LJ, Catney D, Donnelly D, Autier P, et al. (2009) Second primary cancers in patients with skin cancer: a population-based study in Northern Ireland. Br J Cancer 100: 174-177.

52. Calista D (2001) Five cases of melanoma in HIV positive patients. Eur $J$ Dermatol 11: 446-449.

53. Berg D, Otley CC (2002) Skin cancer in organ transplant recipients: Epidemiology, pathogenesis, and management. J Am Acad Dermatol 47: 1-17.

54. Otley CC, Pittelkow MR (2000) Skin cancer in liver transplant recipients. Liver Transpl 6: 253-262.

55. Reutter JC, Long EM, Morrell DS, Thomas NE, Groben PA (2007) Eruptive post-chemotherapy in situ melanomas and dysplastic nevi. Pediatr Dermatol 24: 135-137.

56. Adami J, Gabel H, Lindelof B, Ekstrom K, Rydh B, et al. (2003) Cancer risk following organ transplantation: a nationwide cohort study in Sweden. $\mathrm{Br} \mathrm{J}$ Cancer 89: 1221-1227.

57. Lindelof B, Sigurgeirsson B, Gabel H, Stern RS (2000) Incidence of skin cancer in 5356 patients following organ transplantation. $\mathrm{Br}$ J Dermatol 143: 513-519.

58. Le Mire L, Hollowood K, Gray D, Bordea C, Wojnarowska F (2006) Melanomas in renal transplant recipients. $\mathrm{Br} \mathrm{J}$ Dermatol 154: 472-477.

59. Meyskens FL Jr, Berwick M (2008) UV or not UV: metals are the answer. Cancer Epidemiol Biomarkers Prev 17: 268-270.

60. Bataille V, Bishop JA, Sasieni P, Swerdlow AJ, Pinney E, et al. (1996) Risk of cutaneous melanoma in relation to the numbers, types and sites of naevi: a case-control study. Br J Cancer 73: 1605-1611.

61. Rees JL, Healy E (1997) Melanocortin receptors, red hair, and skin cancer. J Investig Dermatol Symp Proc 2: 94-98.

62. Evans RD, Kopf AW, Lew RA, Rigel DS, Bart RS, et al. (1988) Risk factors for the development of malignant melanoma--I: Review of case-control studies. $J$ Dermatol Surg Oncol 14: 393-408.

63. Franceschi S, Cristofolini M (1992) Cutaneous malignant melanoma: epidemiological considerations. Semin Surg Oncol 8: 345-352.

64. Riley PA (1997) Melanin. Int J Biochem Cell Biol 29: 1235-1239.

65. Rosei MA (2001) Opiomelanins synthesis and properties. Histol Histopathol 16: $931-935$

66. Prota G (1980) Recent advances in the chemistry of melanogenesis in mammals. J Invest Dermatol 75: 122-127.

67. Nordlund JJ (2007) The melanocyte and the epidermal melanin unit: an expanded concept. Dermatologic clinics 25: 271-281.
68. Prota G (2000) Melanins, melanogenesis and melanocytes: looking at their functional significance from the chemist's viewpoint. Pigment Cell Res 13: 283293.

69. Ito S, Wakamatsu K, Ozeki H (2000) Chemical analysis of melanins and its application to the study of the regulation of melanogenesis. Pigment Cell Res 8: 103-109.

70. Simon JD, Peles DN (2010) The red and the black. Acc Chem Res 43: 1452 1460.

71. Hubbard-Smith K, Hill HZ, Hill GJ (1992) Melanin both causes and prevents oxidative base damage in DNA: quantification by anti-thymine glycol antibody. Radiat Res 130: 160-165.

72. Hill HZ (1997) The photobiology of melanin. Photochem Photobiol 65: 471.

73. Wenczl E, Van der Schans GP, Roza L, Kolb RM, Timmerman AJ, et al. (1998) (Pheo)melanin photosensitizes UVA-induced DNA damage in cultured human melanocytes. J Invest Dermatol 111: 678-682.

74. Jimbow K, Salopek TG, Dixon WT, Searles GE, Yamada K (1991) The epidermal melanin unit in the pathophysiology of malignant melanoma. Am J Dermatopathol 13: 179-188.

75. Seiberg M (2001) Keratinocyte-melanocyte interactions during melanosome transfer. Pigment Cell Res 14: 236-242.

76. Andreassi L, Flori ML, Rubegni P (1999) Sun and skin. Role of phototype and skin colour. Adv Exp Med Biol 455: 469-475.

77. Scherer D, Kumar R (2010) Genetics of pigmentation in skin cancer - A review. Mutat Res 705: 141-153

78. Ravnbak MH (2010) Objective determination of Fitzpatrick skin type. Dan Med Bull 57: 4153.

79. Kawada A (2000) Risk and preventive factors for skin phototype. J Dermatol Sci 1: 27-29.

80. Lu H, Edwards C, Gaskell S, Pearse A, Marks R (1996) Melanin content and distribution in the surface corneocyte with skin phototypes. Brit J Dermatol 135 263-267.

81. Valverde P, Healy E, Jackson I, Rees JL, Thody AJ (1995) Variants of the melanocyte-stimulating hormone receptor gene are associated with red hair and fair skin in humans. Nat Genet 11: 328-330.

82. Abdel-Malek Z, Scott MC, Suzuki I, Tada A, Im S, et al. (2000) The melanocortin-1 receptor is a key regulator of human cutaneous pigmentation. Pigment Cell Res 8: 156-162.

83. Evans E, Moggs JG, Hwang JR, Egly JM, Wood RD (1997) Mechanism of open complex and dual incision formation by human nucleotide excision repair factors. EMBO J 16: 6559-6573.

84. Sugasawa K, Ng JM, Masutani C, Iwai S, van der Spek PJ, et al. (1998) Xeroderma pigmentosum group $\mathrm{C}$ protein complex is the initiator of global genome nucleotide excision repair. Mol Cell 2: 223-232.

85. Li RY, Calsou P, Jones CJ, Salles B (1998) Interactions of the transcription/ DNA repair factor TFIIH and XP repair proteins with DNA lesions in a cell-free repair assay. J Mol Biol 281: 211-218.

86. Mu D, Sancar A (1997) Model for XPC-independent transcription-coupled repair of pyrimidine dimers in humans. J Biol Chem 272: 7570-7573

87. Donahue BA, Yin S, Taylor JS, Reines D, Hanawalt PC (1994) Transcript cleavage by RNA polymerase II arrested by a cyclobutane pyrimidine dimer in the DNA template. Proc Natl Acad Sci USA 91: 8502-8506.

88. Reardon JT, Sancar A (2005) Nucleotide excision repair. Prog Nucleic Acid Res Mol Biol 79: 183-235.

89. Park CJ, Choi BS (2006) The protein shuffle. Sequential interactions among components of the human nucleotide excision repair pathway. FEBS J 273:1600-1608.

90. Gillet LC, Scharer OD (2006) Molecular mechanisms of mammalian global genome nucleotide excision repair. Chemical reviews 106: 253-276.

91. Gerard M, Fischer L, Moncollin V, Chipoulet JM, Chambon P, et al. (1991) Purification and interaction properties of the human RNA polymerase $\mathrm{B}$ (II) general transcription factor BTF2. J Biol Chem 266: 20940-20945. 
Citation: Christian P, Vanover J, Scott T, Tullo G, D'Orazio JA (2011) Epidermal Pigmentation, Nucleotide Excision Repair and Risk of Skin Cancer J Carcinogene Mutagene S4:001. doi:10.4172/2157-2518.S4-001

92. Schaeffer L, Roy R, Humbert S, Moncollin V, Vermeulen W, et al. (1993) DNA repair helicase: a component of BTF2 (TFIIH) basic transcription factor. Science 260: 58-63.

93. Schaeffer L, Moncollin V, Roy R, Staub A, Mezzina M, et al. (1994) The ERCC2/ DNA repair protein is associated with the class II BTF2/TFIIH transcription factor. EMBO J 13: 2388-2392.

94. Tapias A, Auriol J, Forget D, Enzlin JH, Scharer OD, et al. (2004) Ordered conformational changes in damaged DNA induced by nucleotide excision repair factors. J Biol Chem 279: 19074-19083.

95. Houtsmuller AB, Rademakers S, Nigg AL, Hoogstraten D, Hoeijmakers JH, et al. (1999) Action of DNA repair endonuclease ERCC1/XPF in living cells. Science 284: 958-961.

96. O'Donovan A, Davies AA, Moggs JG, West SC, Wood RD (1994) XPG endonuclease makes the 3 ' incision in human DNA nucleotide excision repair. Nature 371: 432-435.

97. Sijbers AM, de Laat WL, Ariza RR, Biggerstaff M, Wei YF, et al. (1996) Xeroderma pigmentosum group $F$ caused by a defect in a structure-specific DNA repair endonuclease. Cell 86: 811-822.

98. Igoucheva O, Alexeev V, Scharer O, Yoon K (2006) Involvement of ERCC1/XPF and XPG in oligodeoxynucleotide-directed gene modification. Oligonucleotides 16: 94-104.

99. Winkler GS, Sugasawa K, Eker AP, de Laat WL, Hoeijmakers JH (2001) Novel functional interactions between nucleotide excision DNA repair proteins influencing the enzymatic activities of TFIIH, XPG, and ERCC1-XPF. Biochemistry 40: 160-165.

100. Araujo SJ, Nigg EA, Wood RD (2001) Strong functional interactions of TFIIH with XPC and XPG in human DNA nucleotide excision repair, without a preassembled repairosome. Mol Cell Biol 21: 2281-2291.

101. Miura M, Nakamura S, Sasaki T, Takasaki Y, Shiomi T, et al. (1996) Roles of XPG and XPF/ERCC1 endonucleases in UV-induced immunostaining of PCNA in fibroblasts. Exp Cell Res 226: 126-132.

102. de Laat WL, Appeldoorn E, Sugasawa K, Weterings E, Jaspers NG, et al (1998) DNA-binding polarity of human replication protein A positions nucleases in nucleotide excision repair. Genes Dev 12: 2598-2609.

103. Shivji MK, Podust VN, Hubscher U, Wood RD (1995) Nucleotide excision repair DNA synthesis by DNA polymerase epsilon in the presence of PCNA, RFC, and RPA. Biochemistry 34: 5011-5017.

104. Barnes DE, Tomkinson AE, Lehmann AR, Webster AD, Lindahl T (1992) Mutations in the DNA ligase I gene of an individual with immunodeficiencies and cellular hypersensitivity to DNA-damaging agents. Cell 69: 495-503.

105. Cleaver JE (2005) Cancer in xeroderma pigmentosum and related disorders of DNA repair. Nat Rev Cancer 5: 564-573.

106. Wijnhoven SW, Hoogervorst EM, de Waard H, van der Horst GT, van Steeg $\mathrm{H}$ (2007) Tissue specific mutagenic and carcinogenic responses in NER defective mouse models. Mutat Res 614: 77-94.

107. Moriwaki S, Kraemer KH (2001) Xeroderma pigmentosum--bridging a gap between clinic and laboratory. Photodermatol Photoimmunol Photomed 17: 47-54.

108. van Steeg $\mathrm{H}$, Kraemer KH (1999) Xeroderma pigmentosum and the role of UV-induced DNA damage in skin cancer. Mol Med Today 5: 86-94.

109. D’Errico M, Calcagnile A, Canzona F, Didona B, Posteraro P, et al. (2000) UV mutation signature in tumor suppressor genes involved in skin carcinogenesis in xeroderma pigmentosum patients. Oncogene 19: 463-467.

110. Bau DT, Tsai MH, Huang CY, Lee CC, Tseng HC, et al. (2007) Relationship between polymorphisms of nucleotide excision repair genes and oral cancer risk in Taiwan: evidence for modification of smoking habit. The Chinese journal of physiology 50: 294-300.

111. Berg RJ, de Vries A, van Steeg H, de Gruijl FR (1997) Relative susceptibilities of XPA knockout mice and their heterozygous and wild-type littermates to UVB-induced skin cancer. Cancer Res 57: 581-584.

112. De Ruyck K, Szaumkessel M, De Rudder I, Dehoorne A, Vral A, et al. (2007) Polymorphisms in base-excision repair and nucleotide-excision repair genes in relation to lung cancer risk. Mutat Res 631: 101-110.
113. Itoh T, Linn S, Kamide R, Tokushige H, Katori N, et al. (2000) Xeroderma pigmentosum variant heterozygotes show reduced levels of recovery of replicative DNA synthesis in the presence of caffeine after ultraviolet irradiation. J Invest Dermatol 115: 981-985.

114. Kumar R, Hoglund L, Zhao C, Forsti A, Snellman E, et al. (2003) Single nucleotide polymorphisms in the XPG gene: determination of role in DNA repair and breast cancer risk. Int J Cancer 103: 671-675.

115. Mitra AK, Singh N, Garg VK, Chaturvedi R, Sharma M, et al. (2009) Statistically significant association of the single nucleotide polymorphism (SNP) rs13181 (ERCC2) with predisposition to Squamous Cell Carcinomas of the Head and Neck (SCCHN) and Breast cancer in the north Indian population. J Exp Clin Cancer Res 28: 104

116. Nelson HH, Christensen B, Karagas MR (2005) The XPC poly-AT polymorphism in non-melanoma skin cancer. Cancer Lett 222: 205-209.

117. Wang F, Saito Y, Shiomi T, Yamada S, Ono T, et al. (2006) Mutation spectrum in UVB-exposed skin epidermis of a mildly-affected Xpg-deficient mouse. Environ Mol Mutagen 47: 107-116.

118. Leibeling D, Laspe P, Emmert S (2006) Nucleotide excision repair and cancer. J Mol Histol 37: 225-238.

119. Povey JE, Darakhshan F, Robertson K, Bisset Y, Mekky M, et al. (2007) DNA repair gene polymorphisms and genetic predisposition to cutaneous melanoma. Carcinogenesis 28: 1087-1093.

120. Ibarrola-Villava M, Pena-Chilet M, Fernandez LP, Aviles JA, Mayor M, et al. (2011) Genetic polymorphisms in DNA repair and oxidative stress pathways associated with malignant melanoma susceptibility. Eur J Cancer 47: 2618 2625 .

121. Li C, Hu Z, Liu Z, Wang LE, Strom SS, et al. (2006) Polymorphisms in the DNA repair genes XPC, XPD, and XPG and risk of cutaneous melanoma: a casecontrol analysis. Cancer Epidemiol Biomarkers Prev 15: 2526-2532.

122. Millikan RC, Hummer A, Begg C, Player J, de Cotret AR, et al. (2006) Polymorphisms in nucleotide excision repair genes and risk of multiple primary melanoma: the Genes Environment and Melanoma Study. Carcinogenesis 27 610-618

123. Applebaum KM, Karagas MR, Hunter DJ, Catalano PJ, Byler SH, et al. (2007) Polymorphisms in nucleotide excision repair genes, arsenic exposure, and non-melanoma skin cancer in New Hampshire. Environ Health Perspect 115 1231-1236.

124. de Feraudy S, Ridd K, Richards LM, Kwok PY, Revet I, et al. (2010) The DNA damage-binding protein XPC is a frequent target for inactivation in squamous cell carcinomas. Am J Pathol 177: 555-562.

125.Zhao Q, Barakat BM, Qin S, Ray A, El-Mahdy MA, et al. (2008) The p38 mitogen-activated protein kinase augments nucleotide excision repair by mediating DDB2 degradation and chromatin relaxation. J Biol Chem 283 32553-32561.

126. Fitch ME, Cross IV, Turner SJ, Adimoolam S, Lin CX, et al. (2003) The DDB2 nucleotide excision repair gene product $\mathrm{p} 48$ enhances global genomic repair in p53 deficient human fibroblasts. DNA Repair (Amst) 2: 819-826.

127. Fitch ME, Cross IV, Ford JM (2003) p53 responsive nucleotide excision repair gene products $\mathrm{p} 48$ and XPC, but not p53, localize to sites of UV-irradiationinduced DNA damage, in vivo. Carcinogenesis 24: 843-850.

128. Wakasugi M, Kawashima A, Morioka H, Linn S, Sancar A, et al. (2002) DDB accumulates at DNA damage sites immediately after UV irradiation and directly stimulates nucleotide excision repair. J Biol Chem 277: 1637-1640.

129. Fitch ME, Nakajima S, Yasui A, Ford JM (2003) In vivo recruitment of XPC to UV-induced cyclobutane pyrimidine dimers by the DDB2 gene product. J Bio Chem 278: 46906-46910.

130. Chen JG, Fleischer AB Jr, Smith ED, Kancler C, Goldman ND, et al. (2001) Cost of nonmelanoma skin cancer treatment in the United States. Dermatol Surg 27: 1035-1038.

131. Nag A, Bondar T, Shiv S, Raychaudhuri P (2001) The xeroderma pigmentosum group $E$ gene product DDB2 is a specific target of cullin $4 \mathrm{~A}$ in mammalian cells. Mol Cell Biol 21: 6738-6747.

132. Rapic-Otrin V, McLenigan MP, Bisi DC, Gonzalez M, Levine AS (2002) Sequential binding of UV DNA damage binding factor and degradation of the 
Citation: Christian P, Vanover J, Scott T, Tullo G, D'Orazio JA (2011) Epidermal Pigmentation, Nucleotide Excision Repair and Risk of Skin Cancer J Carcinogene Mutagene S4:001. doi:10.4172/2157-2518.S4-001

p48 subunit as early events after UV irradiation. Nucleic Acids Res 30: 25882598.

133. Ford JM, Hanawalt PC (1995) Li-Fraumeni syndrome fibroblasts homozygous for p53 mutations are deficient in global DNA repair but exhibit normal transcription-coupled repair and enhanced UV resistance. Proc Natl Acad Sci U S A 92: 8876-8880.

134. Bohr VA, Smith CA, Okumoto DS, Hanawalt PC (1985) DNA repair in an active gene: removal of pyrimidine dimers from the DHFR gene of $\mathrm{CHO}$ cells is much more efficient than in the genome overall. Cell 40: 359-369.

135. Mellon I, Bohr VA, Smith CA, Hanawalt PC (1986) Preferential DNA repair of an active gene in human cells. Proc Natl Acad Sci U S A 83: 8878-8882.

136. Mellon I, Spivak G, Hanawalt PC(1987) Selective removal of transcriptionblocking DNA damage from the transcribed strand of the mammalian DHFR gene. Cell 51: 241-249.

137. El-Mahdy MA, Hamada FM, Wani MA, Zhu Q, Wani AA (2000) p53-degradation by HPV-16 E6 preferentially affects the removal of cyclobutane pyrimidine dimers from non-transcribed strand and sensitizes mammary epithelial cells to UV-irradiation. Mutat Res 459: 135-145.

138. Li G, Ho VC, Mitchell DL, Trotter MJ, Tron VA (1997) Differentiation-dependent p53 regulation of nucleotide excision repair in keratinocytes. Am J Pathol 150: 1457-1464.

139. Chen M, Brown P, Botstein D, Ford JM (2002) Global transcriptional responses in human cells following UV-irradiation induced DNA damage. Proc Am Assoc Cancer Res 43: 743 .

140. Adimoolam S, Ford JM (2002) p53 and DNA damage-inducible expression of the xeroderma pigmentosum group C gene. Proc Natl Acad Sci U S A 99: 12985-12990.

141. Hwang BJ, Ford JM, Hanawalt PC, Chu G (1999) Expression of the p48 xeroderma pigmentosum gene is p53-dependent and is involved in global genomic repair. Proc Natl Acad Sci U S A 96: 424-428.

142. Groisman R, Polanowska J, Kuraoka I, Sawada J, Saijo M, et al. (2003) The ubiquitin ligase activity in the DDB2 and CSA complexes is differentially regulated by the COP9 signalosome in response to DNA damage. Cell 113: 357-367.

143. Matsuda N, Azuma K, Saijo M, lemura S, Hioki Y, et al. (2005) DDB2, the xeroderma pigmentosum group $\mathrm{E}$ gene product, is directly ubiquitylated by Cullin 4A-based ubiquitin ligase complex. DNA Repair (Amst) 4: 537-545.

144. Wu YH, Tsai Chang JH, Cheng YW, Wu TC, Chen CY, et al. (2007) Xeroderma pigmentosum group $\mathrm{C}$ gene expression is predominantly regulated by promoter hypermethylation and contributes to p53 mutation in lung cancers. Oncogene 26: 4761-4773.

145. Ming M, Feng L, Shea CR, Soltani K, Zhao B, et al. (2011) PTEN positively regulates UVB-induced DNA damage repair. Cancer Res 71: 5287-5295.

146. Renaud E, Miccoli L, Zacal N, Biard DS, Craescu CT, et al. (2011) Differential contribution of XPC, RAD23A, RAD23B and CENTRIN 2 to the UV-response in human cells. DNA Repair (Amst) 10: 835-847.

147. Resendes KK, Rasala BA, Forbes DJ (2008) Centrin 2 localizes to the vertebrate nuclear pore and plays a role in mRNA and protein export. Mol Cell Biol 28: 1755-1769.

148.Wang QE, Praetorius-Ibba M, Zhu Q, El-Mahdy MA, Wani G, et al. (2007) Ubiquitylation-independent degradation of Xeroderma pigmentosum group $\mathrm{C}$ protein is required for efficient nucleotide excision repair. Nucleic Acids Res 35: $5338-5350$.

149. Wang QE, Zhu Q, Wani G, El-Mahdy MA, Li J, et al. (2005) DNA repair facto XPC is modified by SUMO-1 and ubiquitin following UV irradiation. Nucleic Acids Res 33: 4023-4034.

150. Hardy TM, Kumar MS, Smith ML (2010) RB stabilizes XPC and promotes cellular NER. Anticancer Res 30: 2483-2488.
151. Kang TH, Reardon JT, Sancar A (2011) Regulation of nucleotide excision repair activity by transcriptional and post-transcriptional control of the XPA protein. Nucleic Acids Res 39: 3176-3187.

152. Andrieux LO, Fautrel A, Bessard A, Guillouzo A, Baffet G, et al. (2007) GATA1 is essential in EGF-mediated induction of nucleotide excision repair activity and ERCC1 expression through ERK2 in human hepatoma cells. Cancer Res 67: $2114-2123$

153. Christmann M, Tomicic MT, Aasland D, Kaina B (2007) A role for UV-lightinduced c-Fos: Stimulation of nucleotide excision repair and protection against sustained JNK activation and apoptosis. Carcinogenesis 28: 183-190.

154. Christmann M, Tomicic MT, Origer J, Aasland D, Kaina B (2006) C-Fos is required for excision repair of UV-light induced DNA lesions by triggering the re-synthesis of XPF. Nucleic Acids Res 34: 6530-6539.

155. Potapova O, Haghighi A, Bost F, Liu C, Birrer MJ, et al. (1997) The Jun kinase/ stress-activated protein kinase pathway functions to regulate DNA repair and inhibition of the pathway sensitizes tumor cells to cisplatin. J Biol Chem 272 14041-14044.

156. Rouget R, Auclair Y, Loignon M, Affar el B, Drobetsky EA (2008) A sensitive flow cytometry-based nucleotide excision repair assay unexpectedly reveals that mitogen-activated protein kinase signaling does not regulate the removal of UV-induced DNA damage in human cells. J Biol Chem 283: 5533-5541.

157.Bohm M, Wolff I, Scholzen TE, Robinson SJ, Healy E, et al. (2005) alphaMelanocyte-stimulating hormone protects from ultraviolet radiation-induced apoptosis and DNA damage. J Biol Chem 280: 5795-5802.

158. Hauser JE, Kadekaro AL, Kavanagh RJ, Wakamatsu K, Terzieva S, et al (2006) Melanin content and MC1R function independently affect UVR-induced DNA damage in cultured human melanocytes. Pigment Cell Res 19: 303-314.

159. Passeron T, Namiki T, Passeron HJ, Le Pape E, Hearing VJ (2008) Forskolin Protects Keratinocytes from UVB-Induced Apoptosis and Increases DNA Repair Independent of its Effects on Melanogenesis. J Invest Dermatol 129: 162-166.

160.Smith FJ, Hickerson RP, Sayers JM, Reeves RE, Contag CH, et al. (2008) Development of therapeutic siRNAs for pachyonychia congenita. J Invest Dermatol 128: 50-58.

161. Abdel-Malek ZA, Ruwe A, Kavanagh-Starner R, Kadekaro AL, Swope V, et al. (2009) alpha-MSH tripeptide analogs activate the melanocortin 1 recepto and reduce UV-induced DNA damage in human melanocytes. Pigment Cell Melanoma Res 22: 635-644

This article was originally published in a special issue, Skin Cancer handled by Editor(s). Dr. John D'Orazio, Univ.KY College of Medicine, USA 